Available online at: http://proceeding.rsfpress.com/index.php/ic-smart/index

Proceeding on International Conference of Science Management Art Research Technology

(IC-SMART)

Volume 1 Number 1 (2020): 19-25

\title{
EOQ Inventory Model with Carbon Emission Consideration: A Literature Review
}

\section{Bellachintya Reira Christata, Yosef Daryanto}

Department of Industrial Engineering, Universitas Atma Jaya Yogyakarta, Indonesia

E-mail address bellareira.christata@gmail.com; E-mail address yosef.daryanto@uajy.ac.id

\begin{abstract}
This paper presents a literature review on economic order quantity (EOQ) models that consider carbon emissions. This research aims to analyze the studies about the determination of the optimum re-order amount by implementing EOQ, which considers the carbon emission, published in international journals. It is done by a systematic review process covering publication from 2010 until 2019. This research identifies the key elements of EOQ models under the carbon emission policy investigated in the literature. This research categorizes or groups investigated articles based on the elements. It also presents the main characteristics of the concerning articles with annual publication distribution and the most studied sector. This research is expected to facilitate researchers by identifying and offering several topics, opportunities for the sake of future studies.

The data consists of English articles published in Scopus indexed journals. The research collected, ordered, and reviewed articles from 893 publications. About 29 relevant articles were then analyzed as they met the scope of this research. The findings showed the most promoted matters in developing the EOQ model with carbon emission problems still assumed the types of deterministic demands. This article found some gaps that have not been investigated..
\end{abstract}

Keywords: Economic Order Quantity (EOQ), Inventory, Optimization, Carbon Emission, Literature Review.

\section{INTRODUCTION}

This is an open access article under the CC-BY-NC license

In the last ten years, research on inventory and supply chain model by considering the carbon emission policy has been frequently published. It inspires some researchers to do a literature review. The researchers collected and analyzed various research information based on papers that discussed various inventory models with carbon emission problems. Su et al. (2016) conducted a literature review about a management model under carbon emission policy. They discussed the operational management under carbon emission policy, such as the newsvendor model, economic order quantity (EOQ), and lot sizing in general. Chelly et al. (2019) also conducted a review on supply chain management under carbon emission policy with some logistics decisions (operational management, technology investment, and supply chain design coordination).

Our current research is different from the previous review research. This research comprehensively discusses the single-echelon EOQ inventory model under carbon emission policy. This research aims 
to find the key elements of EOQ under the carbon emission constraints studied in the literature and identify research gaps for future studies. Following this introduction, we present a short literature review in section 2 and explain the research methodology in section 3. Section 4 elaborates on the finding and discusses the result. Finally, Section 5 gives the conclusion and some research suggestions.

\section{LITERATURE REVIEW}

For many years, the accumulation of carbon emissions causes global warming. Many studies show that most carbon emissions come from materials or energy consumed in the production process (Tsiliyannis, 2015). Production activities that can produce carbon emissions are inventory activities, production activities, and transportation (Chelly et al., 2019). Bonney \& Jaber (2011) proposed the idea to study the effect of inventory decisions on carbon emissions. A new inventory cost model is proposed that includes vehicle emissions and waste disposal costs, in addition to ordering costs, purchasing costs, storage costs, and transportation costs. The study developed an EOQ model that suggests a higher order quantity. The idea is continuously growing for about ten years. Many researchers examine the optimum decision considering many managerial situations. However, a literature review that studies comprehensively on the development of this idea is still limited. Hence, our study aims to fill this gap.

Fink (2014) argued that "literature review is a systematic, explicit, and reproducible design for identifying, evaluating, and interpreting the existing body of recorded documents". The objective of a literature review is such as to summarize the existing researches by identifying the patterns, themes, and problems. The second objective of a literature review is to foster conceptual content identification from the field and contribute to developing a theory.

\section{RESEARCH METHODOLOGY}

According to Mayring (2003), a literature review may contain four stages, i.e., material collection, descriptive analysis, category selection, and material evaluation. Hence, each stage of the research methodology in our literature review could be seen in Figure 1.
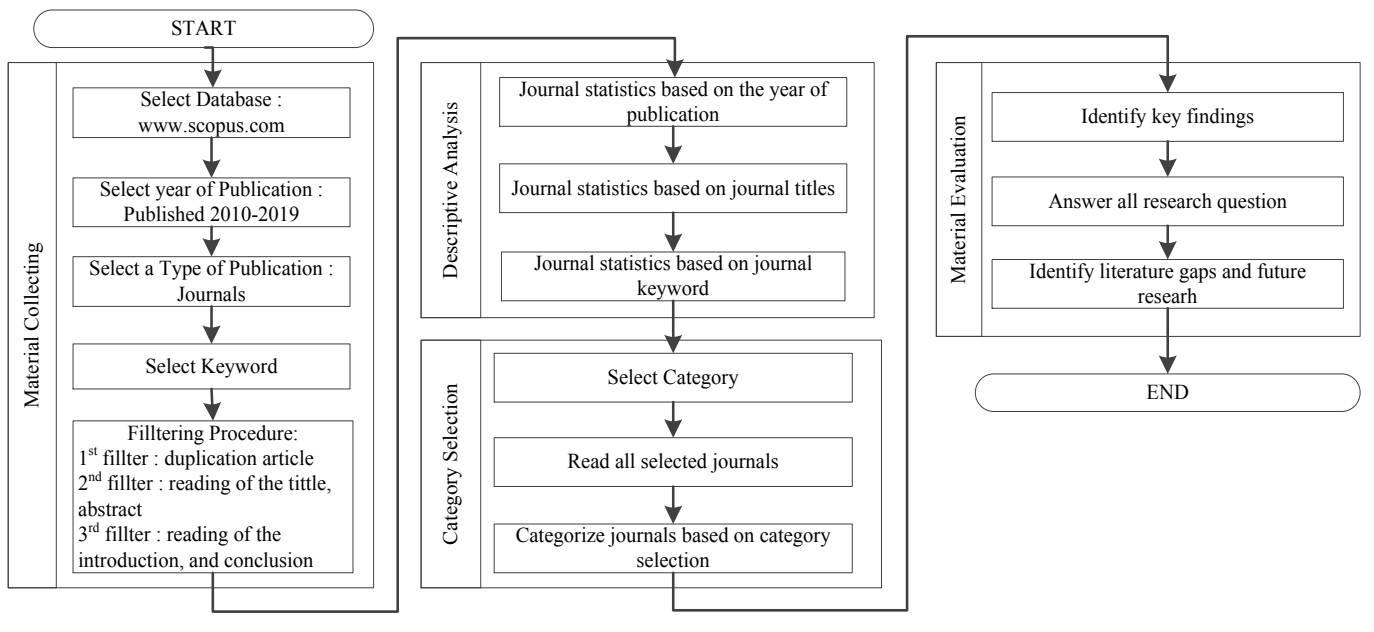

Figure 1. Research methodology 


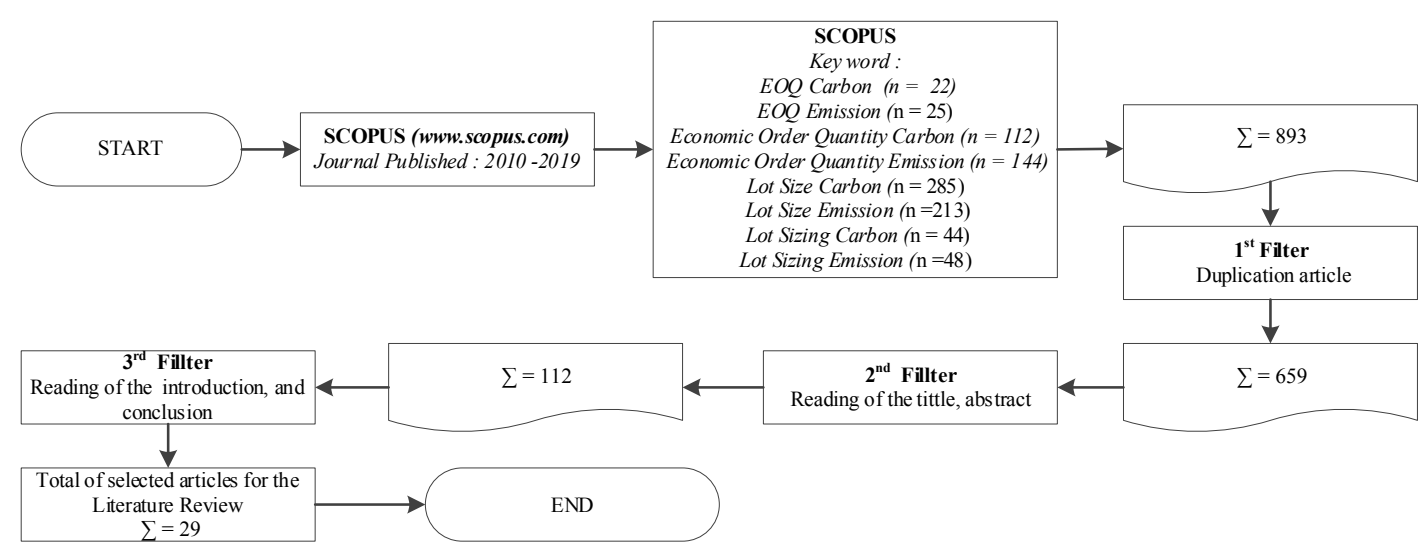

Figure 2. Screening results for material collection

\section{FINDING AND DISCUSSION}

Figure 2 shows the systematic process of the material collection, which includes the database source, keywords, and three filtering processes. The study targeted any published articles in the range of 2010 until October 2019, and Scopus indexed journal in English. Finally, the relevant articles with the topic of one-echelon EOQ with the carbon emission problems consisted of 29 articles. Figure 3 presents the distribution of the article from 2010-2019 that shows the trend on this topic.

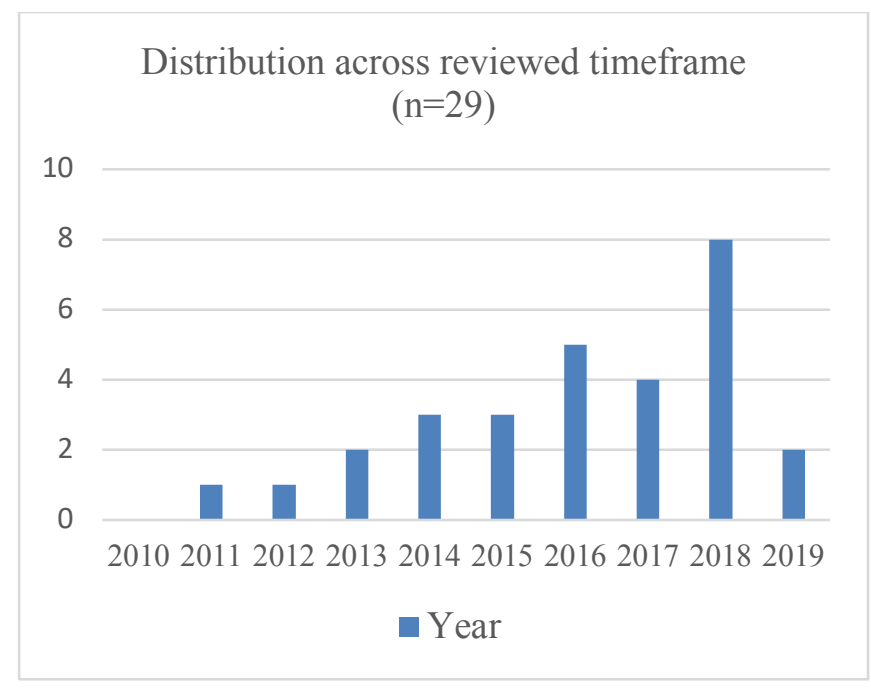

Figure 3. Distribution across a reviewed time frame

From those 29 articles, a detailed review of each article is performed. A categorical analysis is performed based on 16 key topics on the inventory model proposed by Janssen et al. (2016). Table 1 presents the result, including some examples of publications. 
Proceeding on International Conference of Science Management Art Research Technology (IC-SMART),

Vol. 1 (1), 19-25

EOQ Inventory Model with Carbon Emission Consideration: A Literature Review

Bellachintya Reira Christata, Yosef Daryanto

Table 1. Classification based on some key topics

\begin{tabular}{|c|c|c|}
\hline Key topics & $\begin{array}{l}\text { Number of } \\
\text { articles }\end{array}$ & Examples \\
\hline Pricing \& discount & 1 & Taleizadeh et al., 2018 \\
\hline Shortage & 5 & $\begin{array}{l}\text { Taleizadeh et al., 2018; Lee et al., 2017; } \\
\text { Sarkar et al., 2018; Lin, } 2018\end{array}$ \\
\hline Multi-item inventory models & 2 & Lamba and Singh, 2018; Bozorgi, 2016 \\
\hline Inflation and time value of money & 0 & - \\
\hline $\begin{array}{l}\text { Credit and different payment } \\
\text { Problems }\end{array}$ & 2 & Cao et al., 2018; Sarkar et al., 2018 \\
\hline $\begin{array}{l}\text { Investments, Promotion or Budget } \\
\text { Constraint }\end{array}$ & 4 & $\begin{array}{l}\text { Lee, 2019; Toptal et al., 2013; Lin, 2018; } \\
\text { Zhao et al., } 2017\end{array}$ \\
\hline Out-dating, waste or shrinkage & 7 & $\begin{array}{l}\text { Zadjafar and Gholamian, 2018; Kazemi et } \\
\text { al., 2018; Shu et al., 2017; Lin, 2018; } \\
\text { Soleymanfar, } 2015\end{array}$ \\
\hline $\begin{array}{l}\text { Product characteristics or customer } \\
\text { specifics, including behavior, } \\
\text { reservations, returns, etc. }\end{array}$ & 2 & Wu et al., 2017; Bazan et al., 2016 \\
\hline $\begin{array}{l}\text { Issue policies (FIFO, LIFO, etc.) or } \\
\text { substitutions of perishable items }\end{array}$ & 0 & - \\
\hline $\begin{array}{l}\text { Advances in technology (RFID, } \\
\text { TTI) corresponding to inventory } \\
\text { models }\end{array}$ & 1 & Toptal et al., 2013 \\
\hline $\begin{array}{l}\text { Distribution, routing, transportation, } \\
\text { and location problems }\end{array}$ & 4 & $\begin{array}{l}\text { Lee et al., 2017; Wu et al., 2017; Bozorgi et } \\
\text { al., 2014; Zhao et al., } 2017\end{array}$ \\
\hline $\begin{array}{l}\text { Rework, process breakdown, } \\
\text { machine interruption, preventive } \\
\text { maintenance, etc }\end{array}$ & 3 & $\begin{array}{l}\text { Liao and Deng, 2018; Shu et al., 2017; } \\
\text { Sarkar et al., } 2018\end{array}$ \\
\hline Two-and multi-warehouses & 0 & - \\
\hline \multicolumn{3}{|l|}{ Sources of emission } \\
\hline Transportation & 18 & $\begin{array}{l}\text { Wang and Ye, 2018; Tian et al., 2013; Gurtu } \\
\text { et al., 2015; Bouchery et al., 2012; Shu et al., } \\
\text { 2017; Purohit et al., 2013; Bonney \& Jaber, } \\
2011\end{array}$ \\
\hline Production & 8 & $\begin{array}{l}\text { Zadjafar and Gholamian, 2018; Tao and Xu, } \\
\text { 2019; Shu et al., 2017; He et al., 2014; Zhao } \\
\text { et al., } 2017\end{array}$ \\
\hline Inventory & 19 & $\begin{array}{l}\text { Wang and Ye, 2018; Tian et al., 2013; } \\
\text { Kazemi et al., 2018; Chen at al., 2013; }\end{array}$ \\
\hline
\end{tabular}


Proceeding on International Conference of Science Management Art Research Technology (IC-SMART), Vol. 1 (1), 19-25

EOQ Inventory Model with Carbon Emission Consideration: A Literature Review

Bellachintya Reira Christata, Yosef Daryanto

\begin{tabular}{|r|l|l|}
\hline & & $\begin{array}{l}\text { Hovelaque and Bironneau, 2015; Purohit et } \\
\text { al., 2013; Bonney \& Jaber, 2011 }\end{array}$ \\
\hline Carbon emissions legislation & \multicolumn{2}{|l|}{} \\
\hline Carbon cap & 5 & $\begin{array}{l}\text { Liao and Deng, 2018; Lee, 2019; Toptal et } \\
\text { al., 2013; Chen at al., 2013 }\end{array}$ \\
\hline Cap \& Trade & 10 & $\begin{array}{l}\text { Lee, 2019; Toptal et al., 2013; Cao et al., } \\
\text { 2018; Lamba and Singh, 2018 }\end{array}$ \\
\hline Carbon tax & 12 & $\begin{array}{l}\text { Liao and Deng, 2018; Gurtu et al., 2015; } \\
\text { Lee, 2019; Toptal et al., 2013 }\end{array}$ \\
\hline Demand Type & & $\begin{array}{l}\text { Bouchery et al., 2012; Lee, 2019; Toptal et } \\
\text { al., 2013; Taleizadeh et al., 2018; Shu et al., } \\
\text { 2017; Hovelaque and Bironneau, 2015 }\end{array}$ \\
\hline $\begin{array}{r}\text { Deterministic } \\
\text { Zadjafar and Gholamian, 2018; Tian et al., } \\
\text { 2013; Zhang et al., 2019; Lee, 2019; Toptal } \\
\text { et al., 2013; Liao and Deng, 2018 }\end{array}$ \\
\hline $\begin{array}{r}\text { Stochastic (price, stock-level, } \\
\text { or stock-age-dependent } \\
\text { demand, etc.) }\end{array}$ & 13 &
\end{tabular}

The above results show several findings:

a. EOQ models with carbon emissions consideration have been studied in 29 papers from 2011-

2019. This number is increasing, especially in 2018.

b. The EOQ models consider emissions from transportation, production, and inventory holding.

c. The effect of a carbon tax, cap-and-trade, and carbon cap regulations are considered.

d. Most of the reviewed articles applied the deterministic-type demand.

e. This research founds some key topics of the general inventory model that had not been investigated regarding their effect on emission level and costs. It dealt with articles that discussed EOQ with carbon emission problems. The effect of inflation, inventory issuing policy, and multiple-warehouse has not been studied. Besides, the effects of pricing and discount, multi items, payment methods, rework and remanufacturing products, and advanced technology are received little attention.

Further study on the literature found that EOQ models considering carbon emission and environmental impact have higher total costs. It is caused by the additional carbon tax of each production, inventory, or transport activity (Chelly, 2018). Several literature has an objective function of maximizing profits and finds that the greater the carbon emissions released, the smaller the benefits. This is because the total costs increase considering carbon emissions. New models have been created to assist companies in making optimal decisions or improving aspects that can reduce emission levels. For example, companies can invest in technology by using environmentally friendly means of transportation to reduce carbon emissions, thereby reducing total costs incurred.

\section{CONCLUSION AND FURTHER RESEARCH}

This research discusses the single-echelon EOQ inventory model under carbon emission policy. This study identifies 29 papers from the Scopus database. The developed models considering various aspects or key topics in inventory decisions besides environmental factors. The models considered 
Proceeding on International Conference of Science Management Art Research Technology (IC-SMART), Vol. 1 (1), 19-25

EOQ Inventory Model with Carbon Emission Consideration: A Literature Review

Bellachintya Reira Christata, Yosef Daryanto

emissions from transportation, production, and inventory holding. Most of the models assumed a deterministic customer demand and worked under a carbon tax or car-and-trade emission regulations. Several key topics received little attention. Hence, this study recommends further research on the sustainable EOQ model considering the effect of inflation, inventory issuing policy, and multiplewarehouse, the effect of pricing and discount, multi items, payment methods, rework and remanufacturing product, and advance technology. In addition, in the future, a literature review is also needed for EOQ models in multi-echelon supply chain systems.

\section{REFERENCES}

Bazan, E., Jaber, M.Y., \& Zanoni, S. (2016). A review of mathematical inventory models for reverse logistics and the future of its modeling: An environmental perspective, Applied Mathematical Modelling, 40(5-6), 4151-4178.

Bonney, M., \& Jaber, M.Y. (2011). Environmentally responsible inventory models: Non-classical models for a non-classical era, International Journal of Production Economics, 133, 43-53.

Bouchery, Y., Jemal, Z., Ghaffarl, A., \& Dallery, Y. (2012). Including sustainability criteria into inventory models, European Journal of Operation Research, 222(2), 229-240.

Bozorgi, A., Pazour, J., \& Nazzal, D. (2014). A new inventory model for cold items that considers costs and emissions, International Journal of Production Economics, 155, 114-125.

Bozorgi, A. (2016). Multi-product inventory model for cold items with cost and emission consideration, International Journal of Production Economics, 176, 123-142.

Cao, K., Xu, B., He, Y., \& Xu, Q. (2018). Optimal carbon reduction level and ordering quantity under financial constraints, International Transactions in Operational Research, DOI: 10.1111/itor. 12606.

Chelly, A., Nouira, I., Frein, Y., \& Hadj-Alouane, A.B. (2019). On the consideration of carbon emissions in modelling-based supply chain literature: the state of the art, relevant features and research gaps, International Journal of Production Research, 57(15-16), 4977-5004.

Chen, X., Benjaafar, S., \& Elomri, A. (2012). The carbon-constrained EOQ, Operation Research Letters, 41, 172-179.

Fink, A. (2014). Conducting research literature reviews: From the internet to paper. Sage Publications.

Gurtu, A., Jaber, M.Y., \& Searcy, C. (2014). Impact of fuel price and emissions on inventory policies, Applied Mathematical Modelling, 39, 1202-1216.

He, P., Zhang, W., Xu, X., \& Bian, Y. (2015). Production lot-sizing and carbon emissions under capand-trade and carbon tax regulations, Journal of Cleaner Production, 103, 241-248.

Hovelaque, V., \& Bironneau, L. (2014). The carbon-constrained EOQ model with carbon emission dependent demand, International Journal Production Economics, 164, 285-291.

Janssen, L., Claus, T., \& Sauer, J. (2016). Literature review of deteriorating inventory models by key topics from 2012 to 2015, International Journal Production Economics, 182, 86-112.

Kazemi, N., Abdul-Rashid, S.H., Ghazilla, R.A.R., Shekarian, E., \& Zanoni, S. (2018). Economic order quantity models for items with imperfect quality and emission considerations, International Journal of Systems Science: Operation \& Logistics, 5(2), 99-115.

Lamba, K., \& Singh, S.P. (2018). Dynamic supplier selection and lot-sizing problem considering carbon emissions in a big data environment, Technological Forecasting \& Social Change, 144, 573-584.

Lee, S.K., Yoo, S.H., \& Cheong, T. (2017). Sustainable EOQ under lead-time uncertainty and multimodal transport, Sustainability, 9, 476.

Lee, J.Y. (2019). Investing in carbon emissions reduction in the EOQ model, Journal of the Operational Research Society, DOI: 10.1080/01605682.2019.1609889. 
Proceeding on International Conference of Science Management Art Research Technology (IC-SMART), Vol. 1 (1), 19-25

EOQ Inventory Model with Carbon Emission Consideration: A Literature Review

Bellachintya Reira Christata, Yosef Daryanto

Liao, H., \& Deng, Q. (2018). A carbon constrained EOQ model with uncertain demand for remanufactured products. Journal of Cleaner Production, 199, 334-347.

Lin, H. (2018). Investing in transportation emission cost reduction on environmentally sustainable EOQ models with partial backordering, Journal of Applied Science and Engineering, 21(3), 291303.

Mayring, P. (2003). Qualitative inhaltanalyse - Grundlagen und techniken (Qualitative content analysis-Basics and techniques), 8th ed. Weinheim: Beltz Verlag.

Purohit, A.K., Shankar, R., Dey, P.K., \& Choudhary, A. (2016). Non-stationary stochastic inventory lot-sizing with emission and service level constraints in a carbon cap-and-trade system, Journal of Cleaner Production, 113, 654-661.

Sarkar, B., Ahmed, W., Choi, S., \& Tayya, M. (2018). Sustainable inventory management for environmental impact through partial backordering and multi-trade-credit-period, Sustainability, 10,4761 .

Shu, T., Wu, Q., Chen, S., Wang, S., Lai, K.K., \& Yang, H. (2017). Manufacturers'/remanufacturers' inventory control strategies with cap-and-trade regulation, Journal of Cleaner Production, 159, $11-25$.

Soleymanfar, V.R., Taleizadeh, A.A., \& Zia, N.P. (2015). A sustainable lot-sizing model with partial backordering, International Journal of Advanced Operations Management, 7(2), 157.

Su, L., Xiao, B., Suo, C., \& Yang Y. (2016). Models for operation management under carbon policies-A review, Chemical Engineering Transactions, 51, 1159-1165.

Taleizadeh, A.A., Hazarkhan, B., \& Moon, I. (2018). Join pricing and inventory decisions with carbon emission considerations, partial backordering and planned discount, Annals of Operations Research, 1-11, DOI: 10.1007/s10479-018-2968-y.

Tao, Z., \& Xu, J. (2019). Carbon-regulated EOQ models with consumers' low-carbon awareness, Sustainability, 11, 1004.

Tian, Z., Huo, L., \& Shen, G. (2014). Carbon footprint and order quantity in logistics, Journal of Industrial Engineering and Management, 7(2), $475-490$.

Toptal, A., Özlü, H., \& Konur, D. (2013). Joint decisions on inventory replenishment and emission reduction investment under different emission regulations, International Journal of Production Research, 52(1), 243-269.

Tsiliyannis, C.A. (2015). Sustainability by cyclic manufacturing: Assessment of resource preservation under uncertain growth and returns, Resources, Conservation and Recycling, 103, 155-170.

Wang, S., \& Ye, B. (2018). A comparison between just-in-time and economic order quantity models with carbon emissions, Journal of Cleaner Production, 187, 662-671.

Wu, P., Jin, Y., Shi, Y., \& Shyu, H. (2017). The impact of carbon emission costs on manufacturers' production and location decision, International Journal of Production Economics, 193, 193-206.

Zadjafar, M.A., \& Gholamian, M.R. (2018). A sustainable inventory model by considering environmental ergonomics and environmental pollution, case study: Pulp and paper mills, Journal of Cleaner Production, 199, 444-458.

Zhang, R., Liu, Q., \& Wang, C. (2019). Inventory optimization of building materials under the constraints of carbon emissions and stochastic demand, Systems Science \& Control Engineering, 7(1), 146-157.

Zhao, Y.C., Choi, S.H., Wang, X.J., Qiao, A., \& Wang, S.Y. (2017). Production and low-carbon investment analysis in make-to-stock supply chain, Engineering Letters, 25(1), 1-12. 